\title{
Microwave-assisted One-Pot Synthesis of 2-Aryl (1H) Benzimidazoles without Catalyst
}

\author{
Dr. Jassim Mohammed Abdullah \\ Department of Environmental Technology / College of Environment, \\ University of Mosul \\ \& \\ Mohammed Mahmood Sulaiman \\ Department of Environmental Technology / College of Environment, \\ University of Mosul \\ \&

\section{Dr. Salim J. Mohammed} \\ Department of Chemistry / College of Science, \\ University of Mosul
}

Received

01 / 07 / 2010
Accepted

03 / $11 / 2010$

\begin{abstract}
الخلاصة
في هذا البحث تم إجراء طريقة بسيطة وسريعة وكفوة لتحضير سلسلة من مركبات باريل - - بنزيميدازول بوساطة طيف المايكرويف وبدون استخدام مذيب وحفاز وذلك من فن خلال تكائف اورثو - فنيلين ثنائي الامين مع الديهيدات اروماتية مناسبة. تم تشخيص جميع المركبات المحضر ة باستخدام الطرق الفيزيائية والطرق الطيفية
\end{abstract}

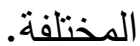

\section{ABSTRACT}

We described a simple, fast and efficient procedure for solvent free Microwave-assisted one pot synthesis of a series of 2-aryl-Hbezimidazoles by condensation of o-Phenylenediamine with suitable aromatic aldehyde. The structures of the products were confirmed by physical and spectral data.

\section{INTRODUCTION}

Benzimidazole derivatives are widely used in medical chemistry and specially in the field of drugs and pharmaceutical ${ }^{(1,2,3)}$. In addition, 
benzimidazoles are very important intermediates in organic synthesis ${ }^{(4,5)}$. Because of their wide range of industrial, pharmacological activity and synthetic applications, many methods have been reported for the synthesis of benzimidazol and 2-substiuted benzimidazoles. Most of these methods involve the condensation of ortho-phenylenediamine, and its derivatives with carboxylic acids, or aldehydes ${ }^{(6-11)}$.

Various catalysed synthesis of benzimidazole derivatives are known condensation of o-phenylenediamine with ortho esters in the presence of various lewis acid catalyst is also known such as $\mathrm{ZrCl}_{4}$, $\mathrm{SnCl}_{4}, \mathrm{TiCl}_{4}, \mathrm{ZrOCl}_{2} .9 \mathrm{H}_{2} \mathrm{O}$ and $\mathrm{HFCl}_{4}{ }^{(9,10,11)}$.

Traditionally, the synthesis of benzimidazoles involve the condensation of o-phenylenediamine with aldehydes, and carboxylic acid or their derivatives in the presence of catalysts ${ }^{(12-14)}$. Under various reaction conditions, or solid supports ${ }^{(15-20)}$.

Recently, a one-pot solvent-free synthesis of biologically active benzimidazole derivative using grinding ${ }^{(21)}$ method and high temperature ( $140{ }^{\circ} \mathrm{C}$ for $1.5-3 \mathrm{~h}$ ), while many published methods are effective, some of these methods suffer from one or more disadvantages such as high reaction temperature, prolonged reaction time, and toxic solvents, or more than one step is involve in the synthesis of these compounds.

In this paper we reported the synthesis of 2-aryl- $(1 \mathrm{H})$ benzimidazole derivatives employing microwave as a heat source to promote the condensation between o-phenylenediamine with suitable aromatic aldehydes without catalyst.

\section{EXPIMENTAL}

All the chemicals used were purchased from either, Fluka or Aldrich companies. Microwave irradiation was done by using a microwave Clatronic domestic oven, 800 watt with frequency of $2450 \mathrm{MHz}$, from Clatronic international $\mathrm{GmbH}$ kempen-Germany. Melting points were determined on Gallen Kamp melting point and are uncorrected. FT-IR spectra were recorded using $\mathrm{KBr}$ disk pye FourierTransform, Tensor Company Bruker 2003. UV spectra were measured on Shimadzu UV-160 Spectrophotometer.

\section{General Procedure}

A mixture of o-phenylenediamine (3mmole, $0.3249 \mathrm{gm}$ ) and aromatic aldehydes $(4.5 \mathrm{mmole})$, was thoroughly ground with a pestle in a mortar at room temperature, then transferred to small beaker or test tube. Microwave irradiation was applied on the reaction mixture at 50\% microwave power level (800 watts) for interval of time specified during 5-10 min. after completion of the reaction, the reaction mixture was cooled to room temperature, washed with water and recrystalized from a suitable solvent, the desired pure products were characterized by 
Dr. Jassim Mohammed Abdullah \& Mohammed Mahmood Sulaiman \& Dr. Salim J. Mohammed

comparison of their physical and spectral data with those of known compounds ${ }^{(21-28)}$.

Table (1): Structural and physical data of the reaction products

\begin{tabular}{|c|c|c|c|c|}
\hline $\begin{array}{l}\text { Aromatic } \\
\text { aldehyde } \\
\text { (R) }\end{array}$ & $\begin{array}{c}\text { 2-Aryl } \\
\text { benzimidazole } \\
\left(\mathbf{R}^{\prime}\right)\end{array}$ & $\begin{array}{c}\text { Time of reaction } \\
\text { (MW-irradiation) } \\
\text { (min) }\end{array}$ & $\begin{array}{l}\text { Yield } \\
\%\end{array}$ & $\begin{array}{c}\text { M.P }{ }^{0} \mathrm{C} \\
\left(\text { Lit. } \mathbf{M . P}{ }^{\circ} \mathrm{C}\right)\end{array}$ \\
\hline $\begin{array}{l}2 \mathrm{a} \\
(\mathrm{H})\end{array}$ & $\begin{array}{l}3 \mathrm{a} \\
(\mathrm{H})\end{array}$ & 8 & 85 & $\begin{array}{l}288-290 \\
(287-288)^{(8,21)}\end{array}$ \\
\hline $\begin{array}{c}2 \mathrm{~b} \\
(4-\mathrm{Cl})\end{array}$ & $\begin{array}{c}3 b \\
(4-C l)\end{array}$ & 5 & 85 & $\begin{array}{l}291-292 \\
(288-291)^{(8,21)}\end{array}$ \\
\hline $\begin{array}{c}2 \mathrm{c} \\
\left(4-\mathrm{NO}_{2}\right)\end{array}$ & $\begin{array}{c}3 \mathrm{c} \\
\left(4-\mathrm{NO}_{2}\right)\end{array}$ & 4 & 88 & $\begin{array}{l}309-310 \\
(308-310)^{(8,21)}\end{array}$ \\
\hline $\begin{array}{c}2 \mathrm{~d} \\
\left(3-\mathrm{NO}_{2}\right)\end{array}$ & $\begin{array}{c}3 \mathrm{~d} \\
\left(3-\mathrm{NO}_{2}\right)\end{array}$ & 4 & 92 & $\begin{array}{l}201-203 \\
(200-202)^{(8)}\end{array}$ \\
\hline $\begin{array}{c}2 \mathrm{e} \\
(2-\mathrm{Cl})\end{array}$ & $\begin{array}{c}3 \mathrm{e} \\
(2-\mathrm{Cl})\end{array}$ & 5 & 83 & $\begin{array}{l}233-234 \\
(230-231)^{(8,21)}\end{array}$ \\
\hline $\begin{array}{c}2 \mathrm{f} \\
\left(4-\mathrm{CH}_{3}\right)\end{array}$ & $\begin{array}{c}3 \mathrm{f} \\
\left(4-\mathrm{CH}_{3}\right)\end{array}$ & 8 & 92 & $\begin{array}{l}261-262 \\
(261-263)^{(8,21)}\end{array}$ \\
\hline$\frac{2 g}{\left(4-\mathrm{OCH}_{3}\right)}$ & $\frac{3 g}{\left(4-\mathrm{OCH}_{3}\right)}$ & 8 & 87 & $\begin{array}{l}226-227 \\
(228-230)^{(8,21)}\end{array}$ \\
\hline $\begin{array}{c}2 \mathrm{~h} \\
(4-\mathrm{OH})\end{array}$ & $\begin{array}{c}3 \mathrm{~h} \\
(4-\mathrm{OH})\end{array}$ & 9 & 89 & $\begin{array}{l}240-242 \\
(240-242)\end{array}$ \\
\hline $\begin{array}{c}2 \mathrm{i} \\
\text {-Furfuraldehyde }\end{array}$ & $\begin{array}{c}3 \mathrm{i} \\
\text { 2-Furyl }\end{array}$ & 8 & 82 & $\begin{array}{l}285-287 \\
(284-286)^{(8,21)}\end{array}$ \\
\hline $\begin{array}{c}2 \mathrm{j} \\
\text { Cinnamaldehyde }\end{array}$ & $\begin{array}{c}3 \mathrm{j} \\
\text { 2-Cinnamyl }\end{array}$ & 10 & 85 & $\begin{array}{l}200-201 \\
(199-201)^{(8)}\end{array}$ \\
\hline
\end{tabular}

\section{RESULTS AND DISSCSION}

In view of the potential medical activity of a number of 2-aryl $(1 \mathrm{H})$ benzimidazole derivatives. In order to establish an optimum condition using microwave irradiation for the synthesis of different substituted benzimidazole (3a-j) by simple condensation of o-pheneylenediamine and different substituted benzaldehydes, Scheme (1).

Inexpensive and readily available domestic microwave oven, transform electromagnetic energy into heat, thus the absorption and transition of the energy varies greatly from that of conventional heating .

In the present study 2 -substitued benzimidazoles were obtained by simple condensation of o-pheneylenediamine and appropriate aromatic benzaldehydes in the solid phase solvent free and under microwave 
irradiation without catalyst. In order to optimized the reaction condition different levels of 800 watt microwave irradiation were applied, and the best level was $50 \%$. All the reaction of different substituted benzaldeydes were carried out under similar condition, and the corresponding were carried out under similar condition, and the corresponding 2-aryl benzimidazoles were obtained in good to excellent yields in short reaction times (5-10 min), Table (1).<smiles>Nc1ccccc1N</smiles>

(I)<smiles>[R]c1ccc(C=O)cc1</smiles>

$2(a-j)$

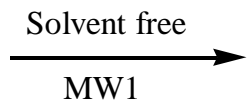

$\mathrm{R}=\mathrm{a}(\mathrm{H}), \mathrm{b}(4-\mathrm{Cl}), \mathrm{c}\left(4-\mathrm{NO}_{2}\right), \mathrm{d}\left(3-\mathrm{NO}_{2}\right), \mathrm{e}(2-\mathrm{Cl}), \mathrm{f}\left(4-\mathrm{CH}_{3}\right), \mathrm{g}\left(4-\mathrm{OCH}_{3}\right), \mathrm{h}(4-\mathrm{OH})$, i(Furfuraldehyde, j(Cinnamaldehyde)

\section{Scheme (1)}

In this study different substituted benzaldehydes (electron with drawing and electrondonating groups) were used to condense with o-phenylene diamine it has been observed that electron withdrawing groups in the aromatic ring of benzaldehyde enhance the reaction rate and reduce the reaction time.

The structure of all the products obtained were known and identified from their spectral data (I.R), Table (2) and comparing their m.p with those reported in literature ${ }^{(8,21,24,25)}$, (Table 1).

Table (2): Spectral data for compound (3a-j)

\begin{tabular}{|c|c|c|c|c|c|c|}
\hline \multirow{2}{*}{$\underset{(\mathbf{R})}{\operatorname{Comp} .}$ No. } & \multirow{2}{*}{$\begin{array}{l}\text { UV (EtOH) } \\
\operatorname{Max}(n m .)\end{array}$} & \multicolumn{5}{|c|}{ I.R $(\mathrm{KBr}) \mathrm{cm}^{-1}$} \\
\hline & & NH & $\mathrm{C}=\mathrm{N}$ & Ar-H & Alkyl (C-H) & Ar (sub.) \\
\hline $\begin{array}{c}3 \mathrm{a} \\
(\mathrm{H})\end{array}$ & 342 & 3390 & 1655 & 3046 & --- & 745 \\
\hline $\begin{array}{c}3 \mathrm{~b} \\
(4-\mathrm{Cl})\end{array}$ & 345 & 3310 & 1658 & 3041 & --- & 825 \\
\hline $\begin{array}{c}3 \mathrm{c} \\
\left(4-\mathrm{NO}_{2}\right)\end{array}$ & 350 & 3355 & 1678 & 3036 & --- & 864 \\
\hline $\begin{array}{c}3 \mathrm{~d} \\
\left(3-\mathrm{NO}_{2}\right)\end{array}$ & 351 & 3240 & 1668 & 3068 & --- & 810 \\
\hline $\begin{array}{c}3 \mathrm{e} \\
(2-\mathrm{Cl})\end{array}$ & 348 & 3350 & 1685 & 3078 & --- & 767 \\
\hline $\begin{array}{c}3 \mathrm{f} \\
\left(4-\mathrm{CH}_{3}\right)\end{array}$ & 346 & 3280 & 1665 & 3080 & 2986 & 832 \\
\hline $\begin{array}{c}3 \mathrm{~g} \\
\left(4-\mathrm{OCH}_{3}\right)\end{array}$ & 352 & 3392 & 1690 & 3062 & 2979 & 826 \\
\hline $\begin{array}{c}3 \mathrm{~h} \\
(4-\mathrm{OH})\end{array}$ & 348 & 3352 & 1646 & 3072 & --- & 918 \\
\hline $\begin{array}{c}3 \mathrm{i} \\
\text { (2-Furfuryl) }\end{array}$ & 354 & 3270 & 1653 & 3086 & --- & 765 \\
\hline $\begin{array}{c}3 \mathrm{j} \\
\text { Cinnamyl }\end{array}$ & 358 & 3310 & 1658 & 3068 & --- & 752 \\
\hline
\end{tabular}


The expected mechanism of the condensation of o-phenylene diamine with different substituted benzaldehydes to from the corresponding 2-substituted benzaldehydes ${ }^{(26,27)}$, (scheme 2).

The aldehyde group initially forms an electrophilic imine linkage by reaction with one of the amine group of o-phenylene diamine, followed by intra-molecular nucleophilic substituted by the remaining amino group in the o-position.

Scheme (2): The expected mechanism.

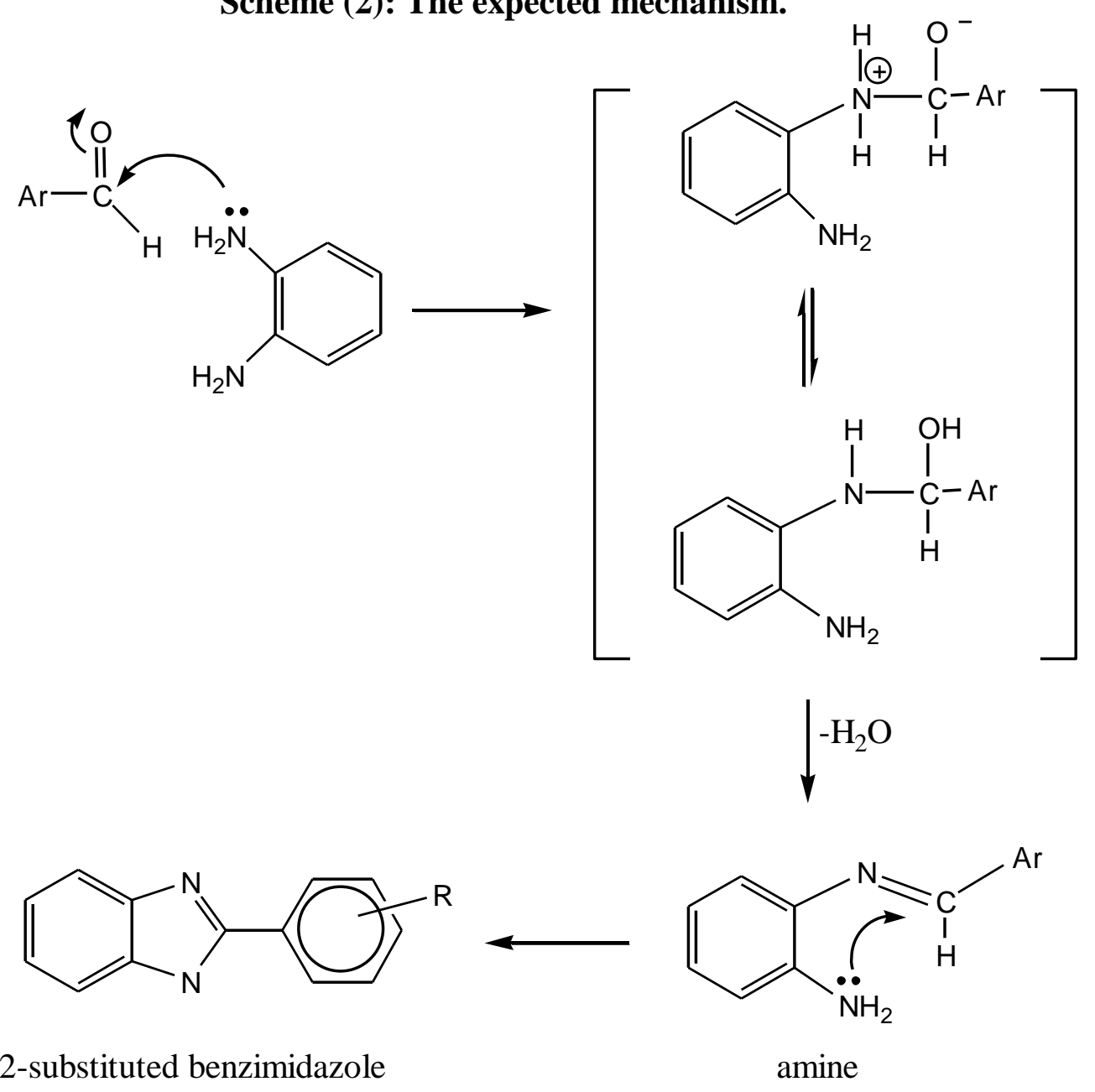

\section{Scheme (2)}

Finally we have developed a simple, and highly efficient, solvent free and environment friend method for the synthesis of 2-aryl $(1 \mathrm{H})$ benzimidazole derivatives, in high yield and short time. 


\section{REFERENCES}

1) D. A. Horton, G. T. Bourne and M. L. Smythe: Chem. Rev., 103, 893, (2003).

2) S. N. Lin, L. H. Yang, Tetrahedron Lett., 46, 3415, (2005).

3) G. L. Gravah, B. C. Baguly, W. R. Wilson and W.A. Denny: J. Med. Chem. 37, 4338, (1994).

4) Y. Bai, J. Lu, Z. Shi and B. Yang: Synlatt., 544, (2000).

5) E. Hasegawa, A. Yoneoka and K. Suzki: Tetrahdron, 55, 12957,(1999).

6) J. B. Wright, Chem. Rev. 48, 397, (1951) and P. N. Preston, Chem. Rev. 74, 279, (1974); see "Comprehensive Reviews on the chemistry of benzaldehydes".

7) T. Harjyoti and D. Gopal: ARKIVOC, (XI), 75, (2008).

8) Hanxiangmine, Ma Huiqiang and Wang Yulu: ARKIVOC, (XIII), 150-154, (2007).

9) Z. H. Zhang and Li. Y. Yin: Tetrahedron Lett. 46, 889, (2005).

10) Z. H. Zhang, L. Yin, Y. Li, Y .M. Wang: Cata. Commun. 8, 1126, (2007).

11) R. Shannaz, M. A. Ali: Monatshefte fur Chemiel Chemical Monthly, 140 (5), 547-552, (2009).

12) S. M. Landge, B. Torok, Catal. Lett., 122, 338 (2008).

13) R. S. Keri, K. M. Hosamani, H. R. Seetharama, R. V. Shingalapur, Cata. Lett., 131, 552 (2009).

14) Y. Chuanming, G. Peng, J. Can., J. Chem. Res., 5, 333 (2009).

15) D. Tumelty, K. Cao, C. P. Holmes, Org. Lett., 3, 83 (2001).

16) D. Tumelty, M. K. Schwarz, M. C. Needels, Tetrahedron Lett., 83, 7467 (1998).

17) J. P. Mayer, G. S. Lewis, C. McGee, Tetrahedron Lett., 39, 6655 (1998).

18) W. Huang, R. M. Scarborogh, Tetrahedron Lett., 40, 2665 (1999).

19) J. P. Kilburn, J. Lau, R. C. Jones, Tetrahedron Lett., 41, 5419 (2000).

20) R. J. Perry, B. D. Wilson, J. Org. Chem., 58, 7016 (1993).

21) T. Harjyoti, D. Gopal: ARKIVOC, (XV), 321-28, (2008).

22) B.A. Abdelkrim, B. Khalid and S. Mohamed: Tetrahedron Lett. 44, 5935, (2003).

23) M. Shen and J. Cai: Flourine Chem., 128, 232, (2007).

24) B. Das, H. Holla and Y. Srinivas: Tehrahedron Lett. 48, 61, (2007).

25) R. Trivedi, S. K. De, R.A. Gibbs, J. M. Cat.: A chemical, 245, 8, (2006).

26) S. Perumal, S. Mariappan and Si, Selvaraj: ARKIVOC, (VIII) 4651, (2004).

27) A. A. Mohammadi, J. Azizian and N. Karimi: Heterocyclic, Vol. 78, No. 9, (2009).

28) R. Kumar and Y.C. Joshi: Journal of Chemistry, Vol. 4, No. 4, , 606-610 (2007). 